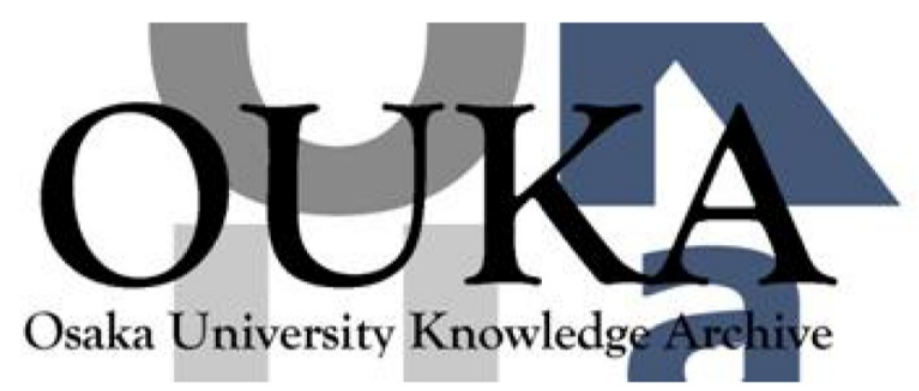

\begin{tabular}{|c|l|}
\hline Title & $\begin{array}{l}\text { 高速応答ビデオサーバ向きの2 層ディスクアレー方 } \\
\text { 式 }\end{array}$ \\
\hline Author(s) & 西村，一敏；丸山，充；阪本，秀樹 他 \\
\hline Citation & $\begin{array}{l}\text { 電子情報通信学会論文誌D-II. J79-D2(10) p. 1686- } \\
\text { p. 1695 }\end{array}$ \\
\hline Issue Date & $1996-10-20$ \\
\hline oaire:version VoR \\
\hline URL & https://hdl. handle.net/11094/23096 \\
\hline rights & Copyright @ (社) 電子情報通信学会 1996 \\
\hline Note & \\
\hline
\end{tabular}

Osaka University Knowledge Archive : OUKA

https://ir. Library. osaka-u. ac. jp/

Osaka University 
高速応答ビデオサーバ向きの 2 層ディスクアレー方式

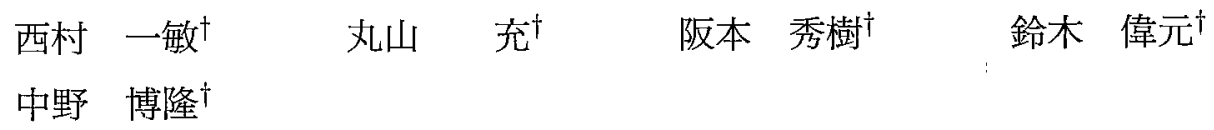

\section{A Double-Layered Disk Array for Quick-Response Video Servers}

Kazutoshi NISHIMURA ${ }^{\dagger}$, Mitsuru MARUYAMA ${ }^{\dagger}$, Hideki SAKAMOTO ${ }^{\dagger}$, Hideharu SUZUKI ${ }^{\dagger}$, and Hirotaka NAKANO ${ }^{\dagger}$

あらまし 読取り制御に循環タイムスロット方式を用いるビデオサーバを対象に，2層ディスクアレー新方式と これに適合したスキップサーチを提案すると共に，性能についての最悪値理論解析を行って以下のことを解明し ている. 今日のバンデッドレコーディング磁気ディスク装置を用いる場合のタイムスロット時間の最悪值は, 最 大アクセス時間と平均データ転送速度というディスク性能で近似できる．単一ディスク従来方式に対するディス クアレー従来方式の読取り多重度の改善倍率は，秒単位実時間の約 $0.7 \sim 1.1$ 倍となる正規化最大待ち時間と 1 の 和が限界值である。新方式では，更に，最大待ち時間で正規化した先頭映像の許容切捨て時間と 1 の和の倍率ま で改善できる.パリティディスクを付加した高信頼 2 層ディスクアレーオ式では，切捨て時間の制約がなければ， サブアレーの並列ディスク台数に数台という最適值が存在する. 更に，ビデオサーバの試作により，提案方式の 機能を検証すると共に，最大待ち時間 1 秒の高速応答と許容切捨て時間 3 秒を条件に, $1.5 \mathrm{Mbit} / \mathrm{s}$ 映像の 100 多 重の読取り性能を実現している。

キーワード ビデオオンデマンド，ビデオサーバ，多重読取り，ディスクアレー

\section{1. まえがき}

近年注目されているビデオオンデマンドでは，蓄積 センタ内の中核装置として, 磁気ディスク装置 $(\mathrm{DK})$ への映像情報の蓄積と多重読取りを行うビデオサーバ が使用される：ビデオサーバ流、, 経済性とサービス 性の観点から，相反関係にある高多重読取りと高速応 答が同時に要求される。映像情報の要求から読取り開 始までの待ち時間を小さく制約した高速応答の条件 では，循環タイムスロット万式 [1]〜 [3] がスキャン方 式 [4],[5]よりも大きな許容多重度を実現できるので 優れている $[4],[6]$.

循環タイムスロット方式を採用する各種ビデオサー バの性能を解明し比較することは，蓄積センタを設計 する上で極めて重要である。しかし，従来の理論解析 は固定デー夕転送速度のDKについてしかなされてお らず [2]〜 [4]，データ転送速度がシリンダ位置に依存 する今日のバンデッドレコーディング DK についての

†NTTヒューマンインタフェース研究所, 武蔵野市 NTT Human Interface Laboratories, 3-9-11 Midori-cho, Musashino-shi, 180 Japan
報告，および最大待ち時間と $\mathrm{DK}$ 総数を同一条件とし た比較についての報告は見当たらない.

本論文では位相シフト時分割多重アクセス方式 [7] を拡張した 2 層ディスクアレー方式とこれに適合した スキップサーチを新たに提案し，これらを試作検証す る.また，理論解析により，バンデッドレコーディン グ DKの読取り処理時間の最悪值を解明し，単一ディ スク [1]〜 [3]，ディスクアレー [1], [4], [5],[8]の両従 来方式と新方式について，最悪值設計により保証でき る許容多重度を最大待ち時問や DK 総数を同一にして 比較する。

2.で読取り処理時間の最悪値を明らかにした後，3. で従来方式の性能を解明する.4.1で2 層ディスクア レー新方式の性能を従来方式と比較し，4.2でパリティ ディスクを付加した高信頼 2 層ディスタアレー方式の 最適構成を明らかにする。4.3でスキップサーチを提 案すると共に，4.4で新技術について試作検証する。

\section{2. タイムスロット時間}

循環タイムスロット方式の多重読取り原理を図 1 に 示す。符号化した映像情報をセグメントと呼ぶ単位に 


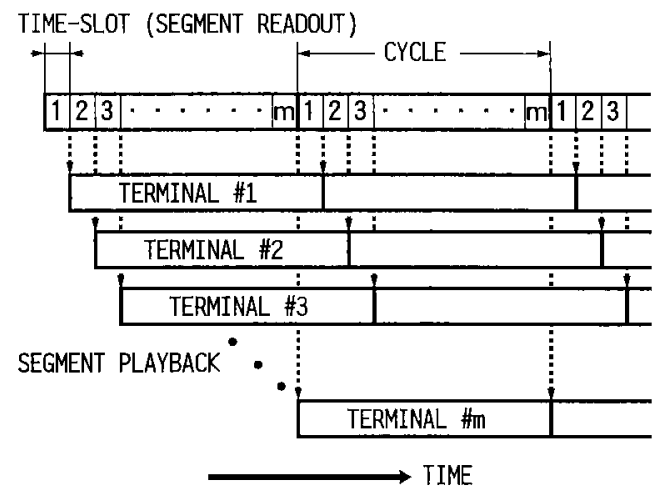

図 1 循㻴タイムスロット方式の多重読取り

Fig. 1 Multiple-readout using cyclic time-slots.

分割して DK に蓄積しておく. DK からは 1 回の処理 で1セグメントを読み取る。セグメントにアクセスし てバッファメモりへ転送している時間をタイムスロッ 卜と乎ぶ。 1 セグメントを端末で復号して再生してい る間に，DKから池他の複数の端末のために順にセグ メントが読み取られる。また，その再生が終了する前 には，後続のセグメントが読み取られて補給される。 このように，循環タイムスロット方式では， $m$ 台の端 末のためにセグメントの読取りを実行する $m$ 個の夕 イムスロットが周期的に繰り返される。

許容多重度を決定するタイムスロット時間は，DK の制御オーバヘッド時間, シーク時間, 回転待ち時間, 招よびセグメントのデータ転送時間の和である．固定 データ転送速度の DK の場合には，シーク時間と回転 待ち時間が最大となる場合に，タイムスロット時間が 最悪となる。しかし，表 1 纪例を示す今日の DKでは， 記憶容量を増大できるバンデッドレコーディングを採 用している。すなわち, 内周から外周に向けてデータ 転送速度が增大するので，最悪タイムスロット時間は 従来のように単純には求まらない。

最悪タイムスロット時間は, デー夕転送速度が最小 となる最内周シリンダ内のセグメントと，あるシリン ダ内のセグメントを交互に読み取る場合に生じる。シ リンダ数から 1 を減じた值を $c$ として, 最内周の隣の シリンダ番号を $1 / c$, 最外周のシリンダ番号を 1 に正 規化して任意のシリンダ番号を $x$ で表すと, 最内周シ リンダとシリンダ $x$ 間のシーク時間 Seek は,

$$
\operatorname{Seek}(x)=\alpha+b \sqrt{x} \quad(1 / c \leqq x \leqq 1)
$$

で近似できる $[9]$. 但し， $a$ と $b$ 㵊小抢よび最大
表 13.5 インチ磁気ディスク装置の仕稼例

Table 1 Example of 3.5-inch disk-drives.

\begin{tabular}{|c|c|c|c|c|}
\hline & I & II & III \\
\hline \multicolumn{2}{|c|}{ フォーマット容量 (MB] } & 1,050 & 4,300 & 4,512 \\
\hline \multicolumn{2}{|l|}{ シリンダ数 } & 3,898 & 3,832 & 4,416 \\
\hline \multicolumn{2}{|l|}{ バンド数 } & 29 & 16 & 10 \\
\hline \multicolumn{2}{|c|}{ 制御オーバヘッド〈 $\mu \mathrm{s}]$} & $\sim 25$ & $\sim 50$ & $\sim 280$ \\
\hline \multirow{2}{*}{$\begin{array}{c}\text { シーク時間 } \\
{[\mathrm{ms}]}\end{array}$} & 最小 & 1 & 0.8 & 0.5 \\
\hline & 最大 & 22 & 20 & 16.5 \\
\hline \multicolumn{2}{|l|}{ 回転数 (rpm) } & 5,400 & 7,200 & 7,200 \\
\hline \multirow{2}{*}{$\begin{array}{c}\text { データ転送速度 } \\
{[\mathrm{Mbit} / \mathrm{s}]}\end{array}$} & 最小 & 37 & 35.4 & 76.7 \\
\hline & 最大 & 62 & 68.3 & 100.6 \\
\hline 信頼度 MTBF & 万時間） & 80 & 80 & 100 \\
\hline
\end{tabular}

シーク時間から求まる定数である。

デー夕転送速度は, 最小值 $D_{\min }$. から最大值 $D_{\text {max }}$. まで $x$ に比例して変化すると仮定する。回転待ち時間 は, 最悪值を議論しているので最大值 $L$ とする. 制 御オーバヘッド時間は，他の時間と此較して十分に小 さいので無視する。このとき, 最内周シリンダ内扝よ びシリンダ $x$ 内のデータ量 $S$ のセグメントを交互に 読み取る場合の 1 セグメント読取り処理当りに平均化 したタイムスロット時間 $T$ は,

$$
\begin{aligned}
T(x)= & \operatorname{Seek}(x)+L \\
& +\frac{S}{2 D_{\min .}}\left(1+\frac{1}{1+(R-1) x}\right)
\end{aligned}
$$

で与えられる。但し， $R$ は

$$
R \equiv D_{\max } / D_{\min }
$$

で定義される速度比である。ここで，付録 1 .より

$$
\theta=M I N[\pi / 6, \tan \sqrt[-1]{R-1}]
$$

として,

$$
S \leqq b D_{m i n .} /\left(\sqrt{R-1} \sin \theta \cos ^{3} \theta\right)
$$

の条件が満足されれば, 式 (2) は単調に増加する. 但 し, $M I N[y, z]$ は $y$ と $z$ のうちで小さい方を与光る 関数である。上記により, 平均化タイムスロット時間 の最悪值は,

$$
\begin{aligned}
& A \equiv a+b+L \\
& D \equiv 2 /\left(1 / D_{\min .}+1 / D_{\max .}\right)
\end{aligned}
$$

で定義される最大アクセス時間 $A$ および逆数で平均 したデータ転送速度 $D$ で表現できる。 


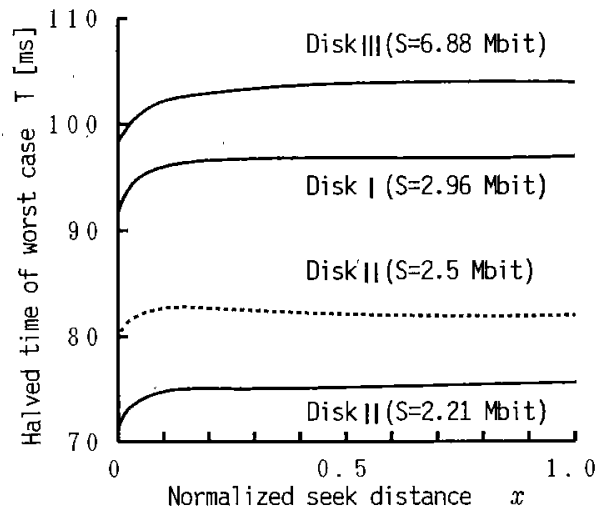

图 22 2 シリンダ交互読取りの処理時間

Fig. 2 Operation time of reciprocal readout from two cylinders.

式 (2) で求めた平均化夕イムスロット時間 $T$ を図 2 に示す．表 1 のDKについて，式 (5) の等号が成立す る条件とした! 繸軸は $T$, 横軸は正規化シーク距離 $x$ を表す． $T$ を単調増加させるセグメントデータ量 $S$ の上限は，DK 個別のデータ転送速度の大きさに比例 して大きくなり，2.21 6.88 Mbitであった．段階的に 変化する真のデー夕転送速度に基づく $T$ は，図 2 に 例示した近似曲線と両端で一致し，途中で複数回交差 する折れ線状となる。この $T$ と近似理論值との間の 誤差は，付録 2.の方法で大きく評価しても，DKのI， II, III について，各々1.1，2.9，1.6\%と十分に小さい. なお，S が大きくなって式 (5) が成立しなくなると， 図 2 に破線で示すように $T$ は $\mathrm{N}$ 字型の曲線へと変化 する。

\section{3. 従来方式の性能}

\section{1 単一ディスク}

セグメントのデータ量 $S$ が 2. の式 (5) を満足する範 囲に扔いて, 許容多重度の最悪値 $M_{s}$ は,

$$
M_{s}=(S / V) /(S / D+A)
$$

で与えられる [2]. 但し， $V$ は映像情報のビットレー トである， $M_{s}$ は㛜密には式 (8)の右辺を超光ない最 大の整数であるが，本諭文では簡略化して実数として 扱う. $M_{s}$ 台の端末から同時に映像情報の要求があり， 最後に処理された先頭セグメントの読取りが完了する までの最大待ち時間 $W$ 㹥，

$$
W=S / V
$$

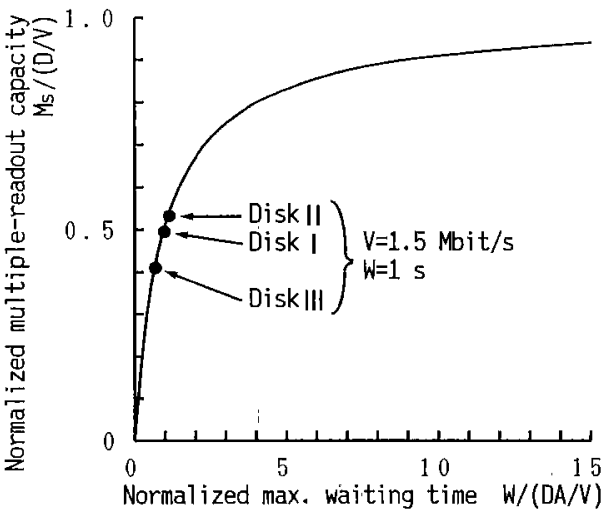

図 3 単一ディスク方式の多重読取り性能

Fig. 3 Multiple-readout performance of a single disk-drive.

で与えられ，周期時間に等しい. 式 (9)を使い式 (8)の $S$ を消去して式 (10) が得られる。

$$
M_{s}=\frac{D}{V} \cdot \frac{V W /(D A)}{1+V W /(D A)}
$$

式 (10)で求めた単一ディスク方式の多重読取り性能 を図 3 に示す。縦軸は $D / V$ で正規化した計容多重度 $M_{s}$, 横軸は $D A / V$ で正規化した最大待ち時間 $W$ を 表す. 図 3 中の点は, $V=1.5 \mathrm{Mbit} / \mathrm{s}, W=1 \mathrm{~s}$ 条 件で, 表 1 の DK で実現できる $M_{s}$ (DKの I, II, III について各々 15，16，23）を示す. 式 (5) の前提条件 が成立する $S$ の最大值で与光られる $W$ は，DK の I, II，III について各々 2.0，1.5，4.6秒である。.これより きW が大きくなると. $M_{s}$ に誤差を生じ，許容多重度 の真の理諭限界である $D_{\min .} / V$ 几漸近する.

従来の $D_{\min }$ ，を用いた最䙳值設計による許容多重 度は，DKの I，II，IIIについて各々 13，14，22であ る。 $D$ を用いた方が，大きくて $15 \%$ 高性能となる。こ の差は， $R, S$ が大きく，Aが小さい活ど大きくなる.

\section{2 ディスクアレー}

ディスクアレー方式は，セグメントを更に細分して 通常の DK 複数台に分散蓄積し，これらを並列に読み 取って DK 台数倍のデー夕転送速度を実現する．DK 総数を $s$ とすれば，1タイムスロットでDK1台から読 み取るデー夕量は, 単一ディスクの場合の $1 / s$ と小さ くなる。従って，式 (5) が単一ディスクで成立してい れば，ディスクアレーでも成立する．以上より，ディ ズクアレーの許容多重度 $M_{a}$ は式 (10)の $D$ を $s D$ に 


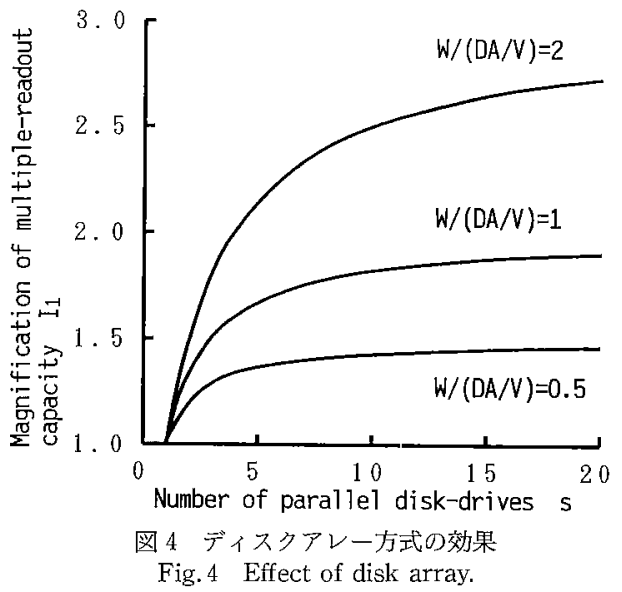

置き換えて,

$$
\begin{aligned}
M_{a} & =\frac{D}{V} \cdot \frac{V W /(D A)}{1+V W /(s D A)} \\
& =\frac{s D / V}{1+s D A /(V W)}
\end{aligned}
$$

で与えられる.䉷密には右辺を超えない整数であるが, $M_{s}$ と同様, 䇛数として扱う. 式 (11) と式 (10)の比で, ディスクアレーの単一ディスクに対寸る許容多重度の 改善倍率 $I_{1}$ を定義する。

$$
I_{1} \equiv \frac{M_{a}}{M_{s}}=\frac{1+V W /(D A)}{1+V W /(s D A)}
$$

式(12)で求めたディスクアレー方式の効果を図 4 に 示す。縦軸は $I_{1}$, 横軸は $\mathrm{DK}$ 総数 $s$ を表す.パラメー 夕として正規化最大待ち時閒を $0.5,1,2$ と変化させ た. 正規化最大待ち時間が小さいほど， $I_{1}$ もささ なり，かつs の増大に伴って早く飽和傾向になること がわかる，これは，最大待ち時間が小さいほどセグメ ントデータ量も小さく，データ転送速度の增大による タイムスロット時間滅少の飽和が早いためである。ま た，いずれの場合比も $I_{1}$ は正規化最大待ち時間と 1 の和で館和する．映像ビットレートを $1.5 \mathrm{Mbit} / \mathrm{s}$ とす ると, 正規化最大待ち時間が 2（DKの I, II，IIIにつ いて各々実時間で $2.0 ， 1.8 ， 2.9$ 秒) の場合でも，改善 は 3 倍以下である.

\section{4. 新 方 式}

\subsection{2 層ディスクアレー}

新たに提案する 2 層ディスクアレー方式の構成を図 5 に示す. DK $p$ 台のディスクアレーである許容多重

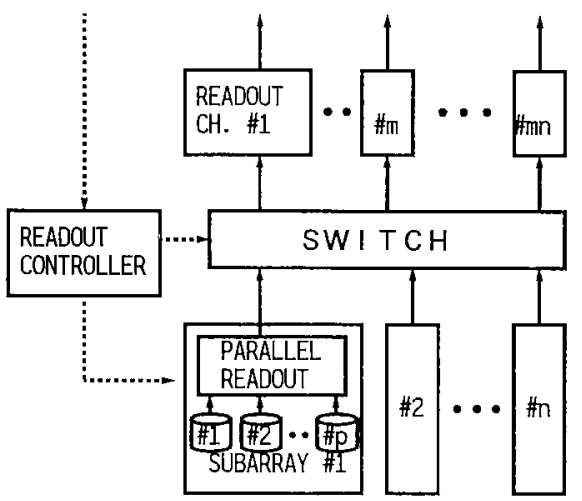

図 52 層ディスクアレー万式のビデオサーバ

Fig.5 Video server with double-layered disk array.

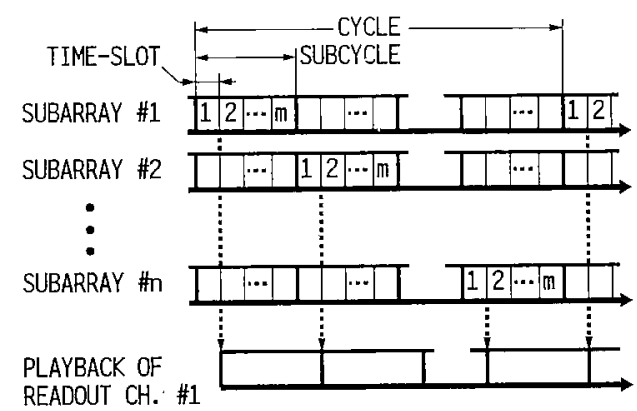

図 62 層ディスクアレー方式の多重読取り動作 Fig.6 Multiple-readout from double-layered disk array.

度 $m$ のサブアレー $n$ 台が，スイッチを介して $m n$ 個 の読取りチャネルと接続される。読取り制御部は，少 プアレーの多重読取りとスイッテの切換えを制御する. 映像情報のセグメントは，先頭からサブアレー1，2， $\ldots n, 1,2, \ldots$ の順に蓄積する。

本方式における多重読取り動作の原理を図 6 に示 す. サブアレーのタイムスロット循環周期を小周期 (Subcycle) と呼ぶ.この小周期ごとに，セグメント の蓄積順にサブアレーを切り換えて読取りを行う. $n$ 台のサブアレーから並行して $m$ 多重の読取りを実行 するので，全体では $m \times n$ の許容多重度が得られる. 許容多重度以内であ玌ば，新規の要求を受け付けた時 点から小周期時間の範囲内でサブアレー1から $n$ の䐓 比調べれば，必ず空きタイムスロットが見つかる。そ こから読取りを開始すれ证先頭部分のセグメントを切 り捨てることになるが，最大待ち時間は小周期時間に 短縮される。

$n=1$ の場合はディスクアレー方式であり, $p=1$ 
の場合は位相シフト時分割多重アクセス方式 [7]であ る.これらと 2 層ディスクアレー方式の優劣を要求条 件と許容多重度の観点加ら明らかにする。また，2層 ディスクアレーはディスクアレーのグループ分けでも 実現できる．実現規模は，インタフェースボードの赛 装量・転送速度に制約されるが，サブアレーを装置と して分離すれば拡大する。な扔，映画ビデオ 20 タイ トルについて調查したところ，製作会社の表示映像か ら本編開始までの時間が 9 秒以上であった。また，約 4 7 分の音楽ビデオ 20 タイトルの場合は, 題名・歌 手名または尊入映像の表示加ら音楽開始までの時間が 6 秒以上で西った。一般的にも同様に，映像情報の先 頭部分の工夫によって, 数秒程度の先頭部切捨ては利 用者の許容範囲にできる。

式(11)の $s$ に置き換えて得られるサブアレー の許容多重度 $m$ が，整数となる場合について考察す る. DK 総数 $s$ には

$$
s=p n
$$

の関係があるので，2 層ディスクアレーの許容多重度 $M_{d}$ は,

$$
\begin{aligned}
M_{d} & =m n \\
& =\frac{p D / V}{1+p D A /(V W)} \cdot n \\
& =\frac{s D / V}{1+p D A /(V W)}
\end{aligned}
$$

で与えられる. 先頭映像の最大切捨て時間 $F$ は,

$$
\begin{aligned}
F & =(n-1) W \\
& =(s / p-1) W
\end{aligned}
$$

となる。式(14)より， $p=1$ かつ $W$ が哲容される範 囲の最大值で $M_{d}$ は最大になり，このとき $n$ に等し いsに比例することがわかる，この場合，サブアレー は単一の DK となり，位相シフト時分俥多重アクセス 方式 [7]そのものとなる.

以下では, 許容切捨て時間 $F_{p}$ が $W$ の整数倍で与 えられ，かつ $F_{p}<F(p=1)$ の場合，すなわち

$$
s>F_{p} / W+1
$$

の場合について考察する。このとき $p$ より $n$ が優先 して制約され，式(15) を $F_{p}$ に等しいと置いて，

$$
n=F_{p} / W+1
$$

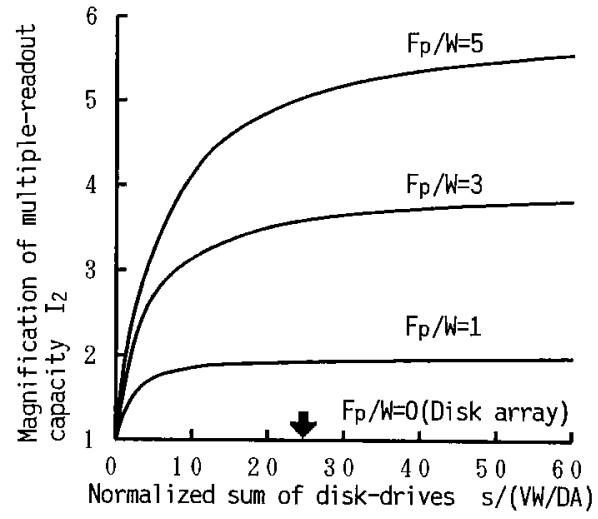

図 72 層ディスクアレー方式の効果

Fig. 7 Effect of double-layered disk array.

を得る. $F_{p}=0$ のときは $n=1$ となり,ディスクア レー方式そのものとなる。式 (14) と式(11)の此で，2 層ディスクアレーのディスクアレーに対する許容多重 度の改善倍率 $I_{2}$ を定義すると,

$$
\begin{aligned}
I_{2} & \equiv \frac{M_{d}}{M_{a}} \\
& =\frac{1+s D A /(V W)}{1+\left(F_{p} / W+1\right)^{-1} s D A /(V W)}
\end{aligned}
$$

となる，但し，式 (13)で $p$ を消去すると共に，式 (17) で $n$ を置き換えた。

式 (18)で求めた 2 層ディスクアレーの効果を図 7 に 示す. 縦軸は $I_{2}$, 横軸は正規化最大待ち時間で正規 化した DK 総数 $s$ を表す。パラメータとして最大待ち 時間 $W$ で正規化した許容切捨て時間 $F_{p}$ を $1,3,5$ と変化させた．正規化許容切捨て時間が大きいほど, $I_{2}$ も大きくなり, かつ $s$ の増大に伴う飽和傾向が緩 和されることがわかる。これは，s の増大に連れて， 式 (11) で与兄られるディスクアレーの許容多重度が飽 和するのに対し，2 層ディスクアレ一の許容多重度は 切捨て時間を増大寸れば比例傾问になるからである。 また，いずれの場合にも $I_{2}$ は正規化許容切捨て時間 と1の和で館和する.

\section{2 高信頼 2 層ディスクアレー}

長時間の映像情報を蓄積する場合には，DK 台数が 多くなるので $\mathrm{DK}$ 故障に備えた対策が必要となる。そ こで, サブアレーごとにパリティDK1台を追加した高 信頼 2 層ディスクアレー方式を提案する [10]. Oyang らも同様の構成を提案しているが，スキャン方式での バッファメモリ削減をねらいとしているので，セグメ ントの蓄積配置と読取り方法が異なる [11]。パリティ 
DKには，DK間にまたがって演算したパリティデー 夕を蓄積する。サブアレー内の 1 台の DK が故障し ても，そのデータは残りの DK のデータから復元でき る.このサブアレーは, RAID (Redundant Arrays of Inexpensive Disks）のレベル 3 または 4 に相当する が，レベル 5 でも同等機能を実現できる，DK 故障が 発生した場合やデータ復元中には，サブアレーの性能 が 10\%程度低下するので，許容多重度を変更して対処 する。

サブアレー内のデータ DK の台数を $p$ とすると, DK 総数 $s$, 許容多重度 $M_{r}$ および最大切捨て時間 $F$ は，各々式 (13)，式 (14)，式 (15) と同様に，

$$
\begin{aligned}
s= & (p+1) n \\
M_{r} & =\frac{p W / A}{p+V W /(D A)} \cdot \frac{s}{p+1} \\
F & =(n-1) W \\
& =\{s /(p+1)-1\} W
\end{aligned}
$$

で与えられる．高信頼 2 層ディスクアレーでは，有効 なデータ DK の台数が DK 総数よりも小さくなるの で，評洒にはこれを加味すべきである．そこで，許容 多重度と, 有効蓄積容量を同一にした蓄積コストとの 比で，評価関数 $E$ を定義する。

$$
\begin{aligned}
E(p) & \equiv M_{r} /\{s(p+1) / p\} \\
& =\frac{W}{A} \cdot \frac{p^{2}}{(p+1)^{2}\{p+V W /(D A)\}}
\end{aligned}
$$

サブアレーに予備 DK を装備する構成もあるが, DK は故障時に取り替光ることを想定して，Eの中には取 替え部品のコス卜（運用経費）は考慮していない.

ここでまず， $F$ が制約されない場合について考察 する. $E の W$ に関する偏導関数は常に正なので, $W$ が許容範囲の最大值のときに $E$ が最大となる、従っ $\tau, W$ は許容最大值とする. $E$ の $p$ 纪関する偏導関 数は $p$ が

$$
P_{\text {opt }} \equiv\{1+\sqrt{1+8 V W /(D A)}\} / 2
$$

で定義される $P_{\text {opt. }}$ のときに0になり，このとき $E$ は最大となる。すなわち，サブアレー内のデータ DK 台数 $p$ には，最適値 $p_{\text {opt }}$. が存在する. $P_{\text {opt. }}$. が整数 の場合は $p_{\text {opt. }}=P_{\text {opt. }}$ である。そうでなければ $P_{\text {opt }}$

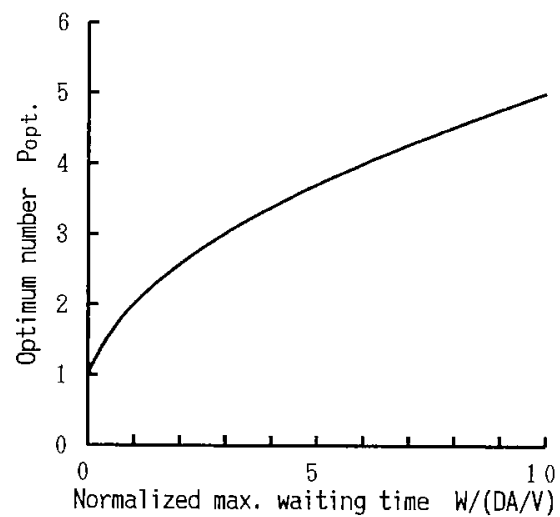

図 8 高信頼 2 層ディスクアレー方式に抢ける並列デー夕 DK 0 最適数

Fig. 8 Optimun number of parallel data disk-drives for redundant double-layered disk array.

の切下げと切上げを行った二つの整数のうち，式 (22) を大きくする方の整数が $p_{\text {opt. }}$ である。

式 (23)で求めた P opt. を図 8 に示す。縦軸は $P_{\text {opt. }}$, 横軸㤬正規化最大待ち時間を表す。正規化最大待ち時 間を 0 加大さくするに連れて， $P_{\text {opt }}$ ， は 1 加ら次第に 大きくなる，これは下記の理由による，最大待ち時間 (周期時間) が十分に小さくて当ブアレーの許容多重度 が $p=1$ で 1 であれば, $p=2$ でも 1 となり，E注式 (22)より各及 $1 / 4$ 稆よび $2 / 9$ となる. すなおち, $p=1$ が最適となる，最大待ち時間を大きくすると，図 4 で 示したように並列 DK 増大による許容多重度改善倍率 が大きくなり，かつ DK 総数に対する有效 $\mathrm{DK}$ 台数の 割合も大きくなるので， $P_{\text {opt }}$. が増大する. 最大待ち 時間が数秒程度の高速応答条件では, サブアレーの並 列 DK は数台が最適である。

次に, 許容切捨て時間 $F_{p}$ が $W$ の整数倍として与 えられ，かつ $F_{p}<F\left(p=p_{\text {opt. }}\right)$ の場合，すなわち

$$
s>\left(p_{\text {opt. }}+1\right)\left(F_{p} / W+1\right)
$$

の場合について考察する。このとき $p$ より $n$ が優先 して制約され，式(21)を $F_{p}$ に等しいとおいて,

$$
\begin{aligned}
& n=F_{p} / W+1 \\
& p=s W /\left(W+F_{p}\right)-1
\end{aligned}
$$

を得る。

以上の高信頼 2 層ディスクアレー方式の設計フロー を図 9 に示す。まず，設計条件として映像ビットレー 


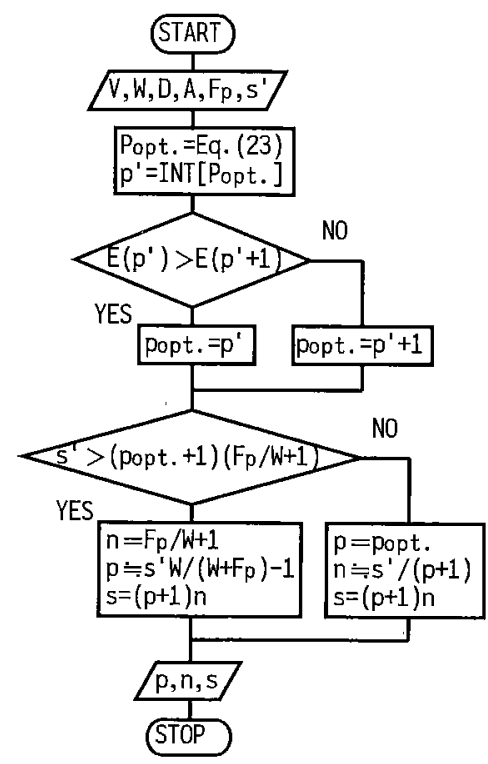

図 9 高信頼 2 層ディスクアレー方式の設計フロー Fig.9 Design flow for redundant double-layered disk array.

卜 $V$, 最大待ち時間 $W, \mathrm{DK}$ の逆数平均デー夕転送 速度 $D$, 最大アクセス時間 $A$, 許容切捨て時間 $F_{p}$, 扝よび仮の DK 総数 $s^{\prime}$ 与光る。次に，評価関数 $E$ を最大にする $P_{\text {opt. }}$ を式 (23) で求め, これに最も近い 万の二つの整数の中で $E$ をより大きくする方を最適 データ DK 台数 $p_{\text {opt }}$ ，とする. 図 9 中の関数 $I N T[y]$ は，yを超えない整数を与える。次に，式 (24)の条件 について調べ，成立する場合にはサブアレー台数 $n$ を 優先して式 (25) で決定すると共に, 式 (26) で得られる 值に近い值にデータ DK 台数 $p$ を決定する. 反対の 場合には，p 優先して $p_{\text {opt. }}$ に決定すると共に，式 (19)で得られる值に近い值に $n$ を決定する．最後に， DK 総数 $s$ が $p+1$ と $n$ の積として確定卞る。

\section{3 スキップサーチ}

ビデオサーバには, 許容多重度を低減させないビ ジュアルサーチが要求される，筆者らが既に提案した 専用データ方式は蓄積データ量を増加させる [8]. 蓄 積データ量の増加がなく，2 層ディスクアレーに適合 したビジュアルサーチの新方式として，スキップサー テを提案する [10], [12]. Chen らが提案している方法 は，これをディスクアレー向きに変形したものとなっ ている [13].

スキップサーチの動作原理をサブアレーが 4 台の場

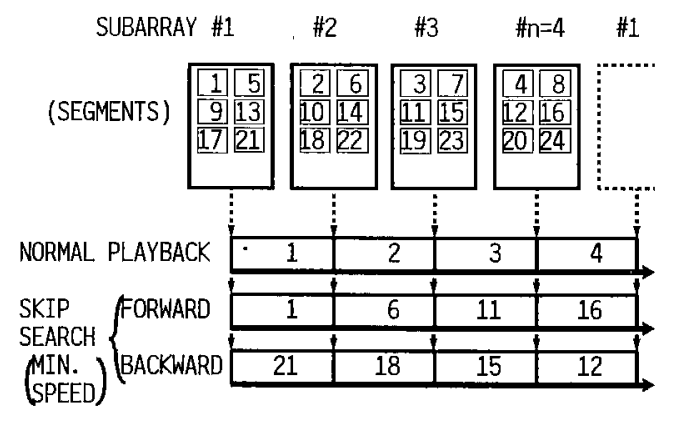

図 10 2 層ディスクアレー万式のスキップサーキ

Fig. 10 Skip search for double-layered disk array.

合例に図 10 に示す。映像情報はセグメントに細分 され，先頭からサブアレー 1，2，3，4 を繰り返す順に 蓄積されている。1 セグメントの再生時間は, 説明の 便宜上 1 秒だと仮定する。セグメントの読取りに使用 するサブアレーは小周期ごとに $1 ， 2 ， 3 ４$ の順に繰り 返して切り換えられ，通常再生の場合は先頭のセグメ ントから順に読み取られる。

順方向のスキップサーチの場合は, 次に使用するサ ブアレーに蓄積されている後続セグメントを1個（一 般には $J$ 個) 飛ばして読み取る。端末では，1秒間の 通常再生の後， 4 秒 (一般には $J \times n$ 秒) 分をスキップ する動作が繰り返される。一方, 逆方向のスキップサー チの場合には，次に使用するサブアレーに蓄積されて いる先行セグメントを読み取る（一般には $J-1$ 個飛 ばして読み取る)。端末では，1秒間の通常再生の後, 2 秒（一般には $J \times n-2$ 秒）分をスキップする動作 が繰り返さ和る。 $J$ を指定することにより，J×n+1 倍速の順方向スキップサーチ, および $J \times n-1$ 倍速 の逆方向スキップサーチを実現できる。

\section{4 試作ビデオサーバ}

高信頼 2 層ディスクアレー方式およびスキップサー チを採用したビデオサーバを試作し，これらの機能を 検証した．試作ビデオサーバの構成を図 11 に，その 外観を図 12 に示す．映像音声情報は MPEG（Moving Picture Coding Experts Group) -1 で符号化し, そ

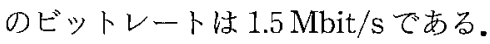

最大待ち時間は 1 秒, 従ってセグメントを 15 フレー ムの GOP (Group of Pictures) 二つ分とした。また, $\mathrm{DK}$ 機種は表 1 の, DK 総数は 28 台, 許容切捨て時 間は 3 秒とした。式 (23)より $P_{\text {opt. }}=2.0$ となり, 直 ちに並列データ DKの最適台数として 2 が得られる。 式 (24) の関係が成立するので許容切捨て時間が優先 


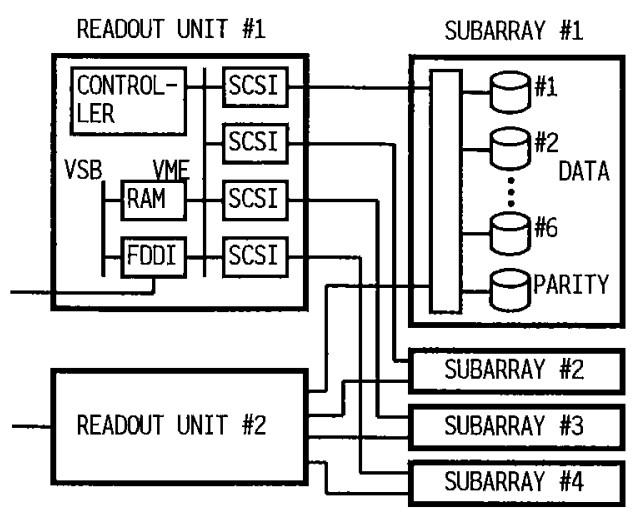

図 11 試作ビデオサーバの構成

Fig. 11 Configuration of experimental video server.

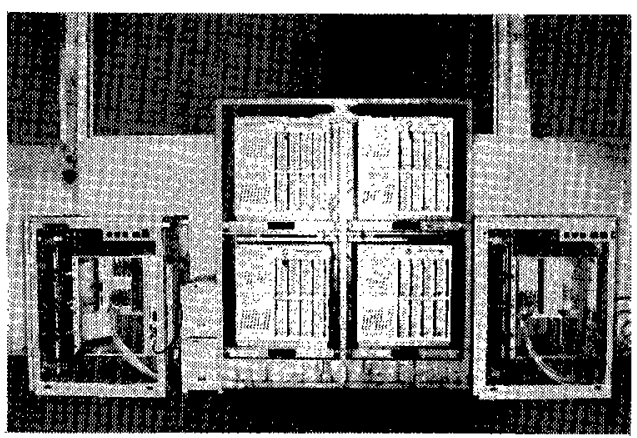

図 12 試作ビデオサーバの外観

Fig. 12 Experimental video server.

されることになり，式 (25) よりサブアレーは 4 台（並 列デー夕DKは 6 台）の構成となる。式 (11) と式 (20) で与えられるサブアレーおよび高信頼 2 層ディスクア レーの許容多重度の最悪理論值は，各々 25 扔よび 100 である．単一ディスクの15多重に対してディスクア レーでは 1.9 倍の 29 多重となり，それよりも更に 3.4 倍の改善効果がある。

端末との通信インタフェースには, TCP/IP (Transmission Control Protocol/Internet Protocol) を高速処理する FDDI（Fiber Distributed Data Interface）ボード [14]を採用した。1枚の通信能力は $1.5 \mathrm{Mbit} / \mathrm{s}$ では 50 チャネルなので，読取りユニット 2 組に各久 2 ホストインタフェースを有するサブアレー 4 台を接続する構成とした。図 5 に示した複数の読取 りチャネルは，バッファメモリ（RAM）のアドレス 空間に分散している。また，スイッチは，サブアレー の 2 ホストインタフェースおよび読取りコニットの
VME (Versa Module Europe) バスに分散している. バッファメモリから高速 FDDI ボードへのデータ転送 には，VSB (VME Subsystem Bus) を採用している.

特殊再生として，ポーズ，コマ送り，スロー，ジヤ ンプ，順逆両方向の早送りおよびスキップサーチを実 現した。低速系の再生は, 読取り扔よび通信の休止と 再開によるフロー制御 [2]で実現した。ジャンプは, 次の小周期で使用するDKに蓄積されているうちで, ジャンプ先に最も近いセグメントから読み取ることで 実現した。従って，読取りの開始時と同様，最大待ち 時間工秒を保証する代わりに, 最大 3 秒分のジャンプ 䛩差を有する，早送りは専用データ方式 [8]で 15 倍速 を実現した。すなわち，15フレームごとに1フレーム を抽出し，これをフレーム内符号化して作成した順方 向と逆方向の専用データをセグメントに分割して蓄積 した。早送りが要求されると，ジャンプと同様に，次 の小周期で使用するDKに蓄積されている要求時点以 降の最も近い専用データセグメントから読取りを開始 する，スキップサーチは，4.3の方法で, 順方向 97 倍, 逆方向 99 倍までの可変速度を実現した。

片方の読取りエニットに端末 9 台を接続し, 残りの 負荷はワークステーションで代行して，100多重の読 取り試験を行った。端末から映像情報を要求して表示 を開始するまでの底答時間は，100多重の負荷をかけ た状態での平均で 1.1 秒であった。このうち，ビデオ サーバが要求を受信して映像情報を送信開始するまで の時閒は， 0.54 秒と高速であった。また，このときス キップサーチなどの特殊再生を実行しても, 他端末で の再生に影響のないことを確認した。以上により, 新 方式の有効性と解析の妥当性が検証できた。

\section{5.むす び}

ビデオオンデマンドの経済性とサービス性の向上を ねらいとして，循環タイムスロット方式に分類される ビデオサーバを刘象に, 新方式の提案, その試作検証, および最悪值理論解析比よる従来方式との性能比較を 行った. 提案した 2 層ディスクアレー新方式は， $m$ 多 重読取りのディスクアレー方式サブアレー $n$ 台によ り， $m \times n$ の許容多重度を可能炕る。かつサブア レーにパリティディスクを付加することにより，大量 映像蓄積時の信頼性を向上できる。提案したスキップ サーチは, 通常再生と同様の読取り動作により, 許容 多重度の劣化なしでビジュアルサーチを可能にする。 試作ビデオサーバでは，映像ビットレート 1.5 Mbit/s， 
先頭映像の切捨て時間 3 秒以下の条件で，100多重の 読取りと待ち時間 1 秒以下の高速応答を達成した。

理論解析では，今日のバンデッドレコーディング DK を使用する場合について，以下のことを解明した．読 取り処理時間の最悪値は, 逆数で平均したデー夕転 送速度と最大アクセス時間で近似できる。映像ビット レート $1.5 \mathrm{Mbit} / \mathrm{s}$ ，最大待ち時間 1 秒の条件では, 単 一ディスク方式の許容多重度恃 20 程度である。これに 対するディスクアレー方式の改善倍率は，秒単位害時 間の約 $0.7 \sim 1.1$ 倍の正規化最大待ち時間と 1 の和が限 界值である。新方式では，更に，最大待ち時間で正規 化した許容切捨て時間と 1 の和の倍率まで改善可能で ある. 高信頼方式のサブアレー内データ DK 台数は, 切捨て時間の制約がなければ数台程度が最啇である。

バンデッドレコーディング DK に関卞る近似が成立 するのは，現状では読取りデータ量が数 Mbit 以下の 場合である。この成立範囲注，今後のデー夕転送速 度の向上に伴って拡大する。性能解析の内容は, 固定 デー夕転送速度の従来型 DKについても成立する。 今 後の課題㤝，スイッテを中心とする拡張性に優れた構 成法の実現である。

謝辞 本研究の機会を与えて頂いた吉利誠メディア 応用システム研究部前部長，ならびに試作ビデオサー バの負荷試験に御協力頂いた関係各位に深謝します。

\section{文献}

[I] K. Nishimura, T. Mori, Y. Ishibashi, and N. Sakurai, "System architecture for digital video-on-demand services," Proc. IEEE Singapore ICIP'92, pp.602-606, Sept. 1992.

[2] 西村一敏, 森 達男, 石橋 豊, “多重読取り可能なビデオオ ンデマンドシステム,"テレビ誌, vol.48, no.3, pp.287-294, March 1994.

[3] P.V. Rangan and H.M. Vin, "Designing file systems for digital video and audio," Proc. ACM SOSP'91, Oper. Sys. Rev., vol.25, no.5, pp.81-94, Oct. 1991.

[4] 梶谷浩一, “動画サーバのためのディスタアレー管理法に ついての考察," 信学諭 (D-I), vol.J77-D-I, no.1, pp.66-76, Jan. 1994.

[5] F.A. Tobagi, J. Pang, R. Baird, and M. Gang, "Streaming RAID $^{T M}$ - A disk array management system for video files," Proc. ACM Multimedia 93, pp.393-400, Aug. 1993.

[6] 鈴木偉元, 阪本秀樹, 西村一敏, “動画情報のディスクア クセス方式の評価,”平 7 前期情処学全大，2G-9.

[7] 阪本秀樹, 西村一敏, 中野博隆, “ビデオ情報の大規模多重 アクセス方式,”信学論 (D-II), vol.J78-D-II, no.1, pp.76-85, Jan. 1995.

[8] T. Mori, K. Nishimura, H. Nakano, and Y. Ishibashi, "Video-on-demand system using optical mass storage system," Jpn. J. Appl. Phys., vol.32, Part 1, no.11B, pp.5433-5438, Nov. 1993.

[9] D. Bitton and J. Gray, "Disk shadowing," Proc. VLDB'88, pp.331-338, Aug. 1988.

［10］西村一敏，阪本秀樹，鈴木偉元，森 達男，“ディジタル動 画情報の高多重読取り方式,”テレビ学技報，vol.18, no.20， pp.1-6, March 1994.

[11] Y. Oyang, M. Lee, C. Wen, and C. Cheng, "Design of multimedia storage systems for on-demand playback," Proc. IEEE Data Engineering'95, pp.457-465, March 1995.

[12] 鈴木偉元, 西村一敏, 阪本秀樹, 森 達男, “多重読取り 特殊再生方法," 特開平 7-226909 (1993-12 出䫧).

[13] M. Chen, D. Kandlur, and P.S. Yu, "Support for fully interactive playout in a disk-array-based video server," Proc. ACM Multimedia 94, pp.391-398, Oct. 1994.

[14] M. Maruyama, O. Nakano, K. Nishimura, and $\mathrm{H}$. Nakano, "Communication processing techniques for multimedia systems," Proc. IEEE Singapore ICCS'94, pp.974-980, Nov. 1994.

\section{付 録}

\section{1. 式 (2) が単調増加する条件}

式(2) を $x$ について微分することにより,

$$
\frac{b}{2 \sqrt{x}}=\frac{S(R-1)}{2 D_{\min .}\{1+(R-1) x\}^{2}}
$$

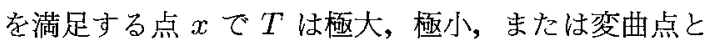
なることがわかる。ここで，

$$
\begin{aligned}
& (R-1) x=\tan ^{2} \theta \\
& \left(\tan ^{-1} \sqrt{(R-1) / c} \leqq \theta \leqq \tan ^{-1} \sqrt{R-1}\right)
\end{aligned}
$$

で置き換えた式 (A-1)の両辺の逆数をとって，

$$
\begin{aligned}
& \frac{\sin \theta}{b \sqrt{R-1} \cos \theta}=\frac{D_{\text {min. }}}{S(R-1) \cos ^{4} \theta} \\
& \therefore \sin \theta \cos ^{3} \theta=b D_{\text {min. }} /(S \sqrt{R-1})
\end{aligned}
$$

を得る。

式 (A.4) の左辺は，凸型の曲線であり， $\theta=\pi / 6$ で 最大值をとる。従って, 式 (A.4) の右辺が十分に大き ければ，式 (A.4)すなわち式 (A.1) は成立しないので, $T$ は単調に増加する。右辺が小さくなって $\theta$ の 1 点で だけ式 (A.4) が成立する場合は，その点で $T$ は変曲点 となるが，単調に増加することに変わりはない，右辺 が更に小さくなると式 (A.4) は $\theta$ の 2 点で成立するこ とになり，最初の点招よび次の点で $T$ は各々極大お よび極小となる。従って， 


$$
\begin{gathered}
\sin \theta \cos ^{3} \theta \leqq b D_{\min .} /(S \sqrt{R-1}) \\
\left(\theta=M I N\left[\pi / 6, \tan ^{-1} \sqrt{R-1}\right]\right)
\end{gathered}
$$

の条件が満足されれば， $T$ は単調増加関数となる.

\section{2. デー夕転送速度の近似による式 (2) の誤差}

デー夕転送速度の近似值と真值の差の絶対值 $d$ を

$$
d=\left(D_{\max .}-D_{\min .}\right) /(B-1)
$$

と見積もる．但し， $B$ はバンド数である．デー夕転 送速度の誤差がシリンダ位置 $x$ によらず一定だとす れば，平均化タイムスロット時間 $T$ に及济す影響は， データ転送速度が最小となる $x=1 / c$ の場合に最大と なる.そこで, $x=1 / c$ でのデー夕転送速度が $D_{\text {min. }}$. よりも $d$ だけ小さかったとして，Tの誤差を大きく見 積もる.このときの平均化タイムスロット時間 $T^{\prime}$ は 最小シーク時間を $a^{\prime}$ として,

$$
T^{\prime}=a^{\prime}+L+\frac{S}{2}\left(\frac{1}{D_{\min .}}+\frac{1}{D_{\min .}-\bar{d}}\right)
$$

で与えられる。従って，過大評価した詋差 $\varepsilon$ は,

$$
\varepsilon=\left\{T^{\prime}-T(1 / c)\right\} / T(1 / c)
$$

となる。

(平成 7 年 6 月 7 日受付, 8 年 3 月 14 日再受付)

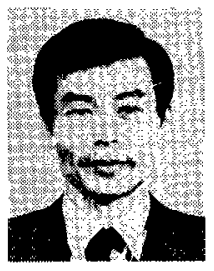

西村 一敏 (正員)

昭 48 熊本大・工・電子卒. 同年日本電信 電話公社 (現 NTT) に入社. 以来, 磁気 テープ記憶装置, 光ディスク装置, マスス トレージシステム，およびビデオオンデマ ンドシステムの研究実用化に從事。現在, NTTヒューマンインタフェース研究所研 究グループリーダ. 応用物理学会会員.

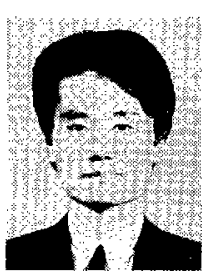

丸山 充 (正員)

昭 60 電通大大学院修士課程了. 同年日本 電信電話 (株) 入社. 以来, メッセージ通 信処理システムの研究，高精細画像情報提 供システムの研究，ビデオオンデマンドシ ステムにおける高速通信処理技術の研究に 従事. 現在, NTT ヒューマンインタフェー ス研究所メディア応用システム研究部主任研究員, 電通大非常 勤講師.ソフトウェア科学会, IEEE 各会員.

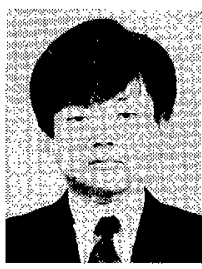

\section{阪本 秀樹 (正員)}

昭 59 阪大・工・通信卒. 昭 61 同大大学 院修士課程了. 同年日本電信電話（株）入 社. 以来, HDTV 高速ビデオテックスシス テム, ビデオオンデマンドシステムの研究 開発纪従事. 現在 NTTヒューマンインタ フェース研究所主任研究員. 情報処理学会,

IEEE, ACM 各会員.

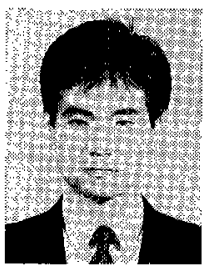

鈴木 偉元 (正員)

平 1 千葉大・工・機械卒, 平 3 同大大学 院修士課程了. 同年日本電信電話 (株) 入 社. 以来, 高精細画像情報提供システム, ビデオオンデマンドの研究開発に従事，現 在 NTTヒューマンインタフェース研究所 メディア応用システム研究部研究主任.

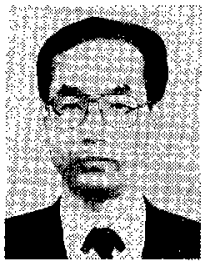

中野 博隆 (正員)

昭 47 東大.工. 電気卒. 昭 52 同大大学 院博士課程了. 同年日本電信電話公社 (現 NTT) に入社. 以来，ビデオテックスシ ステム, ビデオオンデマンドシステムなど 画像通信システムの研究開発に従事. 現在 NTTヒューマンインタフェース研究所メ ディア応用システム研究部部長. 工博. 